\title{
A conversation with Eric Olson
}

E ric Olson of the University of Texas Southwestern Medical Center is best known for his pioneering research on the molecular and genetic mechanisms of cardiac and skeletal muscle development and regeneration. Olson (Figure 1) is also a musician and prize-winning mentor. The full interview (found on the JCI website at www.jci.org/videos/cgms) probes these multiple motivations and includes his replies to questions about whether his hair once had color and if he has ever liked being a department chair.

JCI: Where did you grow up?

Olson: I was born in Rochester, New York. My father grew up on a Norwegian farm in South Dakota without running water and without electricity, and he escaped as soon as he could to go to college and then became a chemist. My father worked at Kodak in Rochester, New York, and there he met my mother. My mother was a musician. She and her mother before her taught piano and music theory at the Eastman School of Music. I was raised in Rochester during my early life, and then my father had an adventurous spirit, so we moved to North Carolina when I was in grade school. I lived next to the campus of Wake Forest University. As I got to high school, we started a more nomadic existence. I went to 10th grade in Richmond, Virginia, 11th grade in Fort Worth, Texas, and 12th grade in a small town in upstate New York called Norwich. By the end of my high school experience, I was ready to find some familiarity again, so I applied to Wake Forest to go back to a place I found familiar.

JCI: What were you like as a kid?

Olson: I was probably an average student. I was always interested in science, even from grade school I remember when the class would go to the library, I would gravitate to the books about science. I knew I would go into some sort of career in science, but coming from a musical family, music was always a part of my life growing up. I started out playing piano as a young child, and then I played trumpet all through high school in the symphony

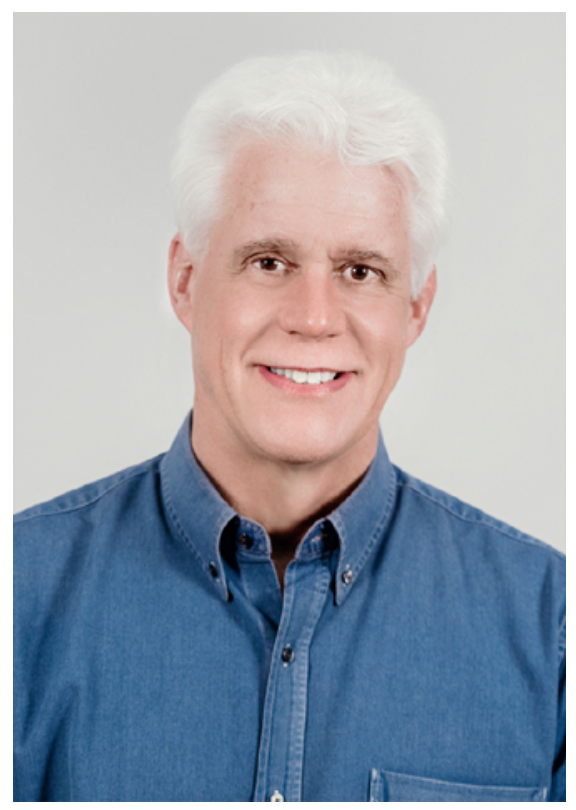

Figure 1. Eric Olson in New York on December 1, 2016. Image credit: Alexey Levchenko.

and jazz orchestra, then later picked up other instruments.

I think my father kindled my interest in science. I was drawn to science, but more to the aspect of learning new things. I was always interested in the edge of knowledge. I was never so interested in memorizing facts. When I got to college, I knew I was going to go into a scientific career, and I double majored in chemistry and biology. But because my high school years had been kind of disruptive due to the multiple moves, I hadn't had a real continuous education through biology and chemistry. So I struggled a bit in my first year of college in the science courses, and I remember my first year advisor said, "Eric, we need to tell you, you don't have a future in science, and you need to start to think about an alternative major."

That was very motivating, and it really encouraged me to redouble my efforts.

JCI: How did you decide to do a PhD?

Olson: I had never, for whatever reason, been interested in applying to medical school. I was more interested in discoverybased science and the freedom to explore things. I decided to stay on at Wake Forest because I was comfortable there. For my $\mathrm{PhD}$, I worked on skeletal muscle membranes, analyzing phospholipid changes that took place in the membranes of muscle during diabetes. It was a very biochemically based project. For my postdoctoral work, I worked in Dr. Luis Glaser's laboratory at Wash U, and that was a real eye-opening experience for me. Wash U was a wonderful scientific environment, and I felt like I'd gone from the $\mathrm{B}$ team into the big leagues. I had a lot of freedom, and I developed a project that connected my prior work with my interests: how lipids were attached to membrane proteins. In particular, I studied a muscle membrane protein, the acetylcholine receptor, which got me interested in the processes of muscle differentiation.

JCI: Did you always want to work in muscle biology?

Olson: At every step in my career, I thought strategically about what I wanted to do. When I finished my postdoc, I applied only for a couple of positions. Glaser, my mentor, told me that a good colleague of his, William Lennarz, was starting a Department of Biochemistry at MD Anderson Cancer Center and he thought that would be a good environment, so I applied there and was fortunate to be hired. At that point, I knew I had to really think about how to carve out a niche and wanted to pick a topic that would sustain me for decades. That was a time when gene regulation was just beginning to be studied; transcription factors hadn't even been cloned yet [in the early 1980s]. Since I knew about muscle, I decided I would study how muscle cells differentiated. Part of that was pragmatic, because you could get a cell line of muscle cells inexpensively and study them and when they differentiated, hundreds of genes would come on, and so it just seemed like a perfect model to try to probe the questions of how batteries of genes get turned on during differentiation.

There was only one problem. I had no experience in molecular biology, and none of the previous labs I'd worked in were molecular biology labs, and so I had to pretty much teach myself from square one.

JCI: When you started your indepen- 
dent lab, was that a successful or difficult experience?

Olson: Maybe fortunately, I was incredibly naive. In the beginning, I didn't know how difficult it would be to establish myself in a new field. I didn't come, as I said, from a background in molecular biology, and I had no experience in gene regulation. But I decided to start simple. I tried to just figure out what DNA sequences turn on one muscle gene. I bought the Maniatis cloning manual and started learning how to do that, and I selected a gene called muscle creatine kinase (MCK). So I wrote my first NIH grant on this; it got completely demolished. That was a little demoralizing. I revised it, sent back the revision; it got demolished again. I'm about three years in, my startup funds are running out, and I tried one more time, and finally I got my R01. I was on my last gasp, but then the momentum started picking up. I was getting some good students. I had some amazing postdocs too in that period. It was gratifying to me that they would bet their careers on me, and happily, many of them are now famous people in the field.

And then, just as these things were really coming together, my department chair, Bill Lennarz, accepted a position at Stony Brook. He asked if I would come with him to a Howard Hughes position there, but I had just spent all these years getting my R01, building my group, and things were coming together. I took my chances on staying, and ironically, a year later, I became the chairman of the department.

JCI: At what point did you pivot towards cardiac muscle from skeletal?

Olson: Well, it goes back to the strategy of the onset of my career. When I first started working on skeletal muscle, I thought if I could discover a couple of interesting genes in skeletal muscle, I might be able to leverage that knowledge to move towards the heart, which is the most interesting muscle of all, but it was a completely intractable organ to study in the early years.

Once my students discovered several of the key genes that orchestrate the formation of muscle, and once we had laid out that framework, then we moved to the heart. Gratifyingly, we discovered some of the key early genes in heart development, such as the HAND genes, myocyte enhancer factor-2 (MEF-2), and myocardin, a master gene for activation of sarcomere genes.

JCI: You started off making a lot of basic biological and developmental discoveries, but you've pivoted towards some regenerative medicine, including a CRISPR/Cas9 model for potentially treating muscular dystrophy. Along the way, you've started three different biotech companies. Where did the entrepreneurial streak come from?

Olson: I always wanted to see our work pushed as far as it could and to go beyond basic science. It became clear as we were working on the early heart gene regulatory programs, particularly when we were studying histone deacetylases and how they're regulated by various kinases, that there was therapeutic potential there. I was involved in starting a company called Myogen Therapeutics, co-founded with two close friends of mine, Mike Bristow and Leslie Leinwand. The work from my lab became a big part of the foundation of that company and also served as an outlet for people from my lab who were interested in biotech. I just found biotech to be so interesting at every level, including coming to Wall Street, trying to raise money when everyone said it wouldn't work.

In academia, everything is interesting. You can go in any direction that you're interested in, and any discovery at the edge of knowledge is important, but in a company, you have to be really focused and practical. Myogen ultimately was acquired along the way, and so then I was able to start another company, miRagen, a microRNAbased company, that has some very exciting things going on. I'm also starting a new company right now to address the issue that you just raised, and that is, can we use gene editing to permanently correct the mutations responsible for muscular dystrophy? I am so excited about this project. I know the challenges, but this is a really exciting time for bringing the technology of gene editing, which was developed by others, to an area where I have expertise: muscle.

JCI: Pivoting to another of your many facets, you play guitar and harmonica and sing in a band. What itch does that scratch?

Olson: I love music and always have. There's usually a song rattling around in my head. I'm not an especially talented musician, but I really enjoy it, and it gives me a creative outlet. One of the things that I'd never done, though, was to play in a rock and roll band; it was always something that
I'd wanted to do. When I was approaching my 50th birthday, I figured I'd better do it. I was fortunate that there were some really good musicians in my department and around UT Southwestern, and so I got them together and we started this band called The Transactivators; it's been awesome. We've played all over the place. I'm kind of a reserved individual, but when I'm with the band and we're up there plugged in and everybody's playing together, you just forget about all that and it feels like I have an alter ego. There's no self-consciousness when you're playing in a band.

JCI: You hold the Annie and Willie Nelson endowed chair. How did that come about?

Olson: Willie Nelson is a national treasure and the greatest icon of Texas. I have always adored his music. It turned out that he and his wife Annie were bringing their two sons to Southwestern for their checkup, and Kern Wildenthal, the president, knew that I was into music, so he arranged for me to have lunch with them, and we really hit it off. So then Willie had a benefit concert and raised money to support the research and to create this Annie and Willie Nelson Chair, and then along the way, I've had many interactions with him on his tour bus before concerts or at his ranch west of Austin.

JCI: Have you ever gotten to play music with him?

Olson: I should do that, but I have not yet. Maybe that's going to be my next goal in life. Being connected to one of my alltime heroes and musical icons, Willie Nelson, has really been a thrill.

JCI: If you couldn't be a scientist, what else do you think could have kept you happy and motivated?

Olson: If I wasn't a scientist, I would have gone into some career that had freedom to operate and an ability to create my own thing. I would not work well in a nineto-five clock-punching mode, so I might have gone into writing or some aspect of music, not necessarily performing, but some aspect of it that has a creative bent. Science is a creative enterprise. It's a really fascinating enterprise when you think about it because it connects extreme creativity with absolute objectivity. And that's what science is; it's the melding of those two extremes.

\section{Ushma S. Neill}

